\title{
Pengaruh Kafein terhadap Tekanan Intraokular
}

\author{
Julian Juanito, ${ }^{1}$ Wenny P. Supit, ${ }^{2}$ Laya M. Rares ${ }^{2}$
}

\author{
${ }^{1}$ Program Studi Pendidikan Dokter Fakultas Kedokteran Universitas Sam Ratulangi, Manado, \\ Sulawesi Utara, Indonesia \\ ${ }^{2}$ Bagian Ilmu Kesehatan Mata Fakultas Kedokteran Universitas Sam Ratulangi Manado, \\ Sulawesi Utara, Indonesia \\ E-mail: julianjuanito@gmail.com
}

\begin{abstract}
High intraocular pressure (IOP) is one of the risk factors of glaucoma or worsening of its prognosis. There are a lot of external factors that can affect IOP inter alia exercise, as well as some food and drinks. One of the drinks that could affect IOP is coffee that contains caffeine. This study was aimed to evaluate whether caffeine had an effect on IOP. This was a literature review study using 4 data bases, as follows: Clinical Key, Pub-med, Google Scholar, and Science Direct. The keywords were Caffeine OR Coffee OR Tea AND IOP OR Intraocular Pressure. Based on inclusion and exclusion criteria, 10 literatures were selected. The results showed that some literatures reported an increase in IOP after caffeine consumption, the others reported a decrease in IOP, meanwhile some others did not find any change of IOP. In conclusion, the effect of caffeine on IOP was acute. People who had high intensity of caffeine consumption had a more significant increase in IOP after consuming caffeine.
\end{abstract}

Keywords: caffeine, intraocular pressure (IOP)

\begin{abstract}
Abstrak: Peningkatan tekanan intraokular (TIO) merupakan salah satu faktor risiko untuk terjadinya glaukoma atau memperburuk prognosis glaukoma. Terdapat banyak faktor eksternal yang dapat memengaruhi TIO, antara lain olahraga, minuman, dan makanan. Salah satu minuman yang dapat memengaruhi TIO ialah kopi yang mengandung kafein. Penelitian ini bertujuan untuk mengetahui adanya pengaruh kafein pada tekanan intraokular. Jenis penelitian ialah literature review. Pencarian data menggunakan empat database yaitu Clinical key, PubMed, Google scholar, dan Science direct. Kata kunci yang digunakan yaitu Caffeine OR Coffee OR Tea AND IOP OR Intraocular Pressure. Seleksi data berdasarkan kriteria inklusi dan ekslusi mendapatkan 10 literatur. Hasil kajian mendapatkan bahwa beberapa penelitian melaporkan adanya peningkatan TIO setelah konsumsi kafein, penelitian lain melaporkan penurunan TIO, dan terdapat pula penelitian yang tidak menemukan perubahan apapun. Simpulan penelitian ini ialah pengaruh kafein pada TIO hanya berlangsung akut. Individu yang memiliki intensitas konsumsi kafein lebih tinggi menunjukkan peningkatan TIO yang lebih nyata setelah mengonsumsi kafein.
\end{abstract}

Kata kunci: kafein, tekanan intraokular (TIO)

\section{PENDAHULUAN}

Peningkatan tekanan intraocular (TIO) merupakan salah satu faktor risiko glaukoma. ${ }^{1}$ Glaukoma adalah penyakit mata yang memengaruhi bagian saraf mata dan merupakan penyebab kebutaan tersering di dunia. $^{2}$ Peningkatan TIO sendiri dapat terjadi karena sekresi cairan humor akueus yang berlebih atau karena tersumbatnya sekresi cairan humor akueus. ${ }^{3,4}$ Sampai saat ini penyebab peningkatan tekanan intraokular masih belum jelas. Peningkatan tekanan intraokular dapat menyebabkan terjadinya glaukoma, yang dapat menyebabkan terjepitnya serabut saraf, dan berlanjut dengan kebutaan jika tidak ditangani dengan tepat. ${ }^{5}$ Banyak aktivitas sehari-hari yang berpotensi meningkatkan 
tekanan intraokular, salah satunya ialah meminum minuman berkafein. ${ }^{6}$ Pada era sekarang semakin banyak orang mengonsumsi minuman berkafein dengan berbagai alasan. Minuman berkafein yang paling sering di konsumsi ialah pertama kopi, dan kedua ialah teh. Seperti yang telah diketahui bersama, budaya minum kopi dan teh di dunia sudah sangat umum. ${ }^{7}$ Penelitian yang membahas tentang pengaruh minuman berkafein terhadap TIO jumlahnya belum terlalu banyak, tetapi dari penelitian yang ada terdapat dua pendapat yang bertentangan; beberapa penelitian menyatakan bahwa peningkatan TIO yang disebabkan oleh kafein itu sendiri tidak cukup berpengaruh untuk menjadikanya faktor risiko glaukoma, tetapi penelitian lainnya menyatakan hal yang berbeda yaitu peningkatan TIO yang disebabkan oleh minuman berkafein cukup berpengaruh terutama pada pasien glaukoma, dan efeknya paling nyata 60-90 menit setelah mengonsumsi minuman tersebut. ${ }^{6,7}$ Berdasarkan latar belakang ini maka penulis tertarik untuk meneliti tentang pengaruh kafein terhadap TIO. ${ }^{6,7}$

\section{METODE PENELITIAN}

Penelitian ini merupakan suatu literature review. Pencarian literatur dilakukan dengan menggunakan mesin pencari khusus artikel ilmiah seperti Pubmed, Clinical Key, Science Direct, dan Google Scholar. Pen- carian dilakukan dengan memasukan kata kunci Caffeine OR Coffee OR Tea AND IOP OR Intraocular Pressure dengan berbagi variasi dan terjemahan. Artikel yang ditemukan kemudian diskrining menggunakan kriteria inklusi dan eksklusi dengan membaca judul dan cuplikan abstrak dari artikel tersebut. Artikel penelitian yang memenuhi syarat skrining selanjutnya dibaca keseluruhanya untuk memastikan informasinya dapat digunakan untuk menjawab tujuan penelitian.

Pada penelitian ini didapatkan literatur sebanyak 34 Google scholar, 426 Pubmed, 23 Science Direct yang sesuai dengan kata kunci tersebut. Hasil pencarian yang sudah didapatkan kemudian dilakukan skrining berdasarkan judul yang sesuai dengan tema literature review dan didapatkan 25 artikel. Selanjutnya 25 jurnal tersebut diskrining abstrak dan fulltext berdasarkan kriteria inklusi dan eklusi dan didapatkan 10jurnal yang dipergunakan dalam kajian ini.

\section{HASIL PENELITIAN}

Setelah melakukan seleksi literatur didapatkan 10 artikel yang memenuhi kriteria inklusi, terdiri dari 3 randomized controlled trial, 3 cross-over study, dan 4 prospective study. Tabel 1 memperlihatkan hasil kajian kesepuluh artikel yang diperoleh dari berbagai negara di dunia.

Tabel 1. Hasil kajian literatur yang digunakan dalam penelitia

\begin{tabular}{|c|c|c|c|c|}
\hline Peneliti, Tahun & Lokasi & $\mathbf{N}$ & Intervensi & Hasil \\
\hline Ebeigbe et al, $2013^{8}$ & Benin & 50 & $\begin{array}{l}\text { Pemberian air sebanyak } \\
250 \text { ml terhadap kelompok } \\
\text { A, dan pemeberian } 250 \mathrm{ml} \\
\text { kopi yang mengandung } 85 \\
\text { mg kafein pada kelompok } \\
\text { B. }\end{array}$ & $\begin{array}{l}\text { Tidak ada perubah TIO } \\
\text { yang bermakna pada } \\
\text { setiap periode waktu } \\
\text { pengukuran }(\mathrm{p}=>0,05) \\
\text { pada grup kontrol. }\end{array}$ \\
\hline Azimah et al, $2015^{9}$ & $\begin{array}{l}\text { Kelatan, } \\
\text { Malaysia }\end{array}$ & 91 & $\begin{array}{l}\text { Pada penelitian tidak dibe- } \\
\text { rikan intervensi melainkan } \\
\text { mengunakan dietary food } \\
\text { recall }\end{array}$ & $\begin{array}{l}\text { Tidak ditemukan per- } \\
\text { ubahan pada TIO yang } \\
\text { bermakna dari hasil } \\
\text { penelitian }(p=>0,05)\end{array}$ \\
\hline Putri et al, $2013^{10}$ & $\begin{array}{l}\text { UJS } \\
\text { Purwokerto } \\
\text { Indonesia }\end{array}$ & 74 & $\begin{array}{l}\text { Pemberian kafein seba- } \\
\text { nyak } 80 \mathrm{mg} \text { terhadap ke- } \\
\text { lompok A, dan pemeberian } \\
\text { kafein sebanyak } 4 \mathrm{mg} \text { pada } \\
\text { kelompok B. }\end{array}$ & $\begin{array}{l}\text { Ditemukan } \\
\text { peningkatan TIO yang } \\
\text { bermakna pada menit } \\
\text { ke } 60 \text {, dan } 90 . \\
(p=<0,05)\end{array}$ \\
\hline Chandra et al,2011 11 & Baltimore & 5 & $\begin{array}{l}\text { Pemberian kafein dalam } \\
\text { bentuk obat tetes mata }\end{array}$ & $\begin{array}{ll}\text { Tidak } & \text { ditemukan } \\
\text { peningkatan } & \text { pada TIO }\end{array}$ \\
\hline
\end{tabular}




\begin{tabular}{|c|c|c|c|c|}
\hline & & & $\begin{array}{l}\text { kafein } 100 \mathrm{mg} \text { yang di } \\
\text { larutkan ke dalam air } 10 \mathrm{ml} \\
\text { yang kemudian di bagi } \\
\text { menjadi } 1 \mathrm{ml} .\end{array}$ & sama sekali. \\
\hline Avisar et al, $2002^{12}$ & $\begin{array}{l}\text { Robin Medical } \\
\text { Center }\end{array}$ & 28 & $\begin{array}{l}\text { Pemberian minuman ber- } \\
\text { kafein yang mengandung } \\
180 \text { mg kafein pada } \\
\text { kelompok A dan pem- } \\
\text { berian minuman decaf } \\
\text { yang hanya mengandung } \\
3,8 \text { mg kafein pada kelom- } \\
\text { pok B selama } 10 \text { hari } \\
\text { masing-masing. }\end{array}$ & $\begin{array}{l}\text { Ditemukan pening- } \\
\text { katan TIO yang cukup } \\
\text { bermakna pada menit } \\
\text { ke } 60 \text {, dan } 90 \text { pada } \\
\text { kelompok A, dengan } \\
\text { nilai p=0,013 dan } \\
p=0,024\end{array}$ \\
\hline Jiwani et al, $2012^{13}$ & Massachusetts & 106 & $\begin{array}{l}\text { Pemberian minuman seba- } \\
\text { nyak } 237 \text { ml pada kedua } \\
\text { kelompok dimana salah sa- } \\
\text { tunya mengandung kafein } \\
\text { dan satunya minuman } \\
\text { decaf. }\end{array}$ & $\begin{array}{l}\text { Tidak ditemukan pe- } \\
\text { ningkatan TIO yang } \\
\text { bermakna secara statis- } \\
\text { tik dari kedua kelom- } \\
\text { pok kontrol }(\mathrm{p}=>0,05)\end{array}$ \\
\hline $\begin{array}{l}\text { Fidelman et al, } \\
2019^{14}\end{array}$ & RSU Ahoda & 100 & $\begin{array}{l}\text { Pemberian kopi Nescafe } \\
\text { sebanyak } 0,7 \mathrm{ml} / \mathrm{kg} \mathrm{BB} \\
\text { pada kelompok } \mathrm{A}, 2,1 \mathrm{ml} / \\
\text { kg BB pada kelompok B, } \\
3,5 \mathrm{ml} / \mathrm{kg} \mathrm{BB} \text { pada kelom- } \\
\text { pok C, dan pemeberian } \\
600 \mathrm{ml} \text { air tanpa kafein } \\
\text { pada kelompok D. }\end{array}$ & $\begin{array}{l}\text { Ditemukan pening- } \\
\text { katan TIO yang ber- } \\
\text { makna pada semua } \\
\text { kelompok }(\mathrm{p}=<0,05) \\
\text { kecuali kelompok kon- } \\
\text { trol dimana tidak dite- } \\
\text { mukan perubahan yang } \\
\text { bermakna. }(\mathrm{p}=>0,05)\end{array}$ \\
\hline Pasquale et al,2012 & United States & 120,179 & $\begin{array}{l}\text { Pada penelitian tidak dibe- } \\
\text { rikan intervensi melainkan } \\
\text { mengunakan dietary food } \\
\text { recall }\end{array}$ & $\begin{array}{l}\text { Tidak ditemukan per- } \\
\text { ubahan yang secara } \\
\text { statistik bermakna de- } \\
\text { ngan p=0,03 (nilai } \\
\text { perubahan bermakna } \\
(\mathrm{p}=<0,05)\end{array}$ \\
\hline Kang et al, $2008^{16}$ & United States & 121,172 & $\begin{array}{l}\text { Pada penelitian tidak dibe- } \\
\text { rikan intervensi melain- } \\
\text { kan mengunakan dietary } \\
\text { food recall }\end{array}$ & $\begin{array}{l}\text { Tidak ditemukan pe- } \\
\text { ningkatan TIO yang } \\
\text { bermakna pada peserta } \\
\text { penelitian yang mende- } \\
\text { rita glaukoma sudut } \\
\text { terubuka tetapi dite- } \\
\text { mukan peningkatan } \\
\text { bermakna pada pende- } \\
\text { rita glaukoma sudut } \\
\text { terbuka tensi tinggi. }\end{array}$ \\
\hline Ajayi et al, $2001^{17}$ & Benin & 40 & $\begin{array}{l}\text { Kelompok A mengon- } \\
\text { sumsi } 100 \mathrm{ml} \text { kopi biasa, } \\
\text { dan kelompok B mengon- } \\
\text { sumsi } 100 \mathrm{ml} \text { kopi decaf. }\end{array}$ & $\begin{array}{l}\text { Tidak ditemukan per- } \\
\text { ubahan bermakna pada } \\
\text { penelitian }(\mathrm{p}=0,038)\end{array}$ \\
\hline
\end{tabular}

\section{BAHASAN}

Kafein diperkirakan dapat menyebabkan terjadinya penghambatan fosfodiesterase yang mengakibatkan tingginya tingkat siklik adenosin monofosfat (cAMP) pada badan siliaris dan produksi berlebih dari humor akueus yang berperan dalam peningkatan TIO. Konsumsi kafein juga dapat menyebabkan penurunan sekresi cairan dengan mengurangi tonus otot polos dan penyempitan pori-pori trabekuler. Kafein telah terbukti mengurangi aliran darah ke makula, saraf optikus, dan koroid. ${ }^{18}$

Hasil kajian artikel yang dipakai dalam penelitian ini menunjukkan bahwa pengaruh kafein pada TIO masih belum konklusif. Perubahan TIO yang dilaporkan dalam beberapa penelitian tidak bermakna seperti pada penelitian oleh Azimah et $\mathrm{al}^{9}$ yang 
menyatakan bahwa peningkatan TIO yang dialami setelah mengonsumsi kafein terutama pada menit ke 30, 60 dan 90 tidak cukup bermakna. Para peserta penelitiannya terdiri dari kelompok pasien dengan glaukoma sudut terbuka dan glaukoma sudut terututup, Hasil penelitian tersebut selaras dengan penelitian Ebeigbe dan Obahiagbon $^{8}$ yang mendapatkan penurunan TIO pada peserta penelitian yang merupakan orang-orang sehat yang mengonsumsi kafein, namun penurunan tersebut tidak bermakna secara statistik. Chandra et $\mathrm{al}^{11}$ juga menyatakan bahwa tidak terdapat perubahan TIO pada peserta penelitian yang merupakan pasien glaukoma sudut terbuka walapun peserta penelitian tidak mengonsumsi kafein secara langsung tetapi dalam bentuk tetes mata. Hal ini menunjukkan bahwa terdapat kemungkinan peningkataan TIO yang dialami orang-orang yang mengonsumsi kafein disebabkan unsur lain dari minuman-minuman tersebut, tetapi beum ada pembuktian. ${ }^{8,9,11}$

Disisi lain, penelitian oleh Putri et a ${ }^{10}$ melaporkan bahwa kafein dapat meningkatkan TIO. Peserta penelitiannya terdiri dari orang sehat yang tidak memiliki risiko glaucoma. Hasil yang serupa juga didapatkan oleh Avisar et al ${ }^{12}$ yaitu kafein mampu meningkatkan TIO peserta penelitian yang terdiri dari kelompok pasien glaukoma normotensif dan pasien dengan hipertensi okular terutama pada menit 60 dan 90 atau secara singkat. Hasil penelitian Fidelma dan Sydney ${ }^{14}$ mendapatkan hal yang sejalan pada peserta penelitiannya yang terdiri dari kelompok orang sehat tanpa riwayat kelainan refraksi atau infeksi, riwayat operasi mata dan memiliki TIO yang normal. Peningkatan TIO didapatkan pada semua kelompok penelitian kecuali pada kelompok kontrol yang merupakan satu-satunya kelompok yang tidak mengonsumsi kafein. ${ }^{10,12,14}$

Tekanan intraokular (TIO) dapat dipengaruhi oleh berbagai faktor, diantaranya ialah kelainan refraksi, olahraga, dan juga makanan dan minuman, namun masih banyak faktor-faktor yang belum sepenuhnya dipertimbangkan oleh literatur yang dipakai dalam penelitian ini. Selain itu, pengaruh kafein terhadap TIO sendiri belum memiliki hasil yang konklusif dan masih perlu penelitian lebih lanjut. ${ }^{18-20}$

\section{SIMPULAN}

Pengaruh kafein pada TIO haanya berlansung akut dan individu yang memiliki intensitas konsumsi kafein lebih tinggi menunjukan peningkatan TIO yang lebih nyata setelah mengonsumsi kafein.

\section{Konflik Kepentingan}

Penulis menyatakan tidak terdapat konflik kepentingan dalam studi ini.

\section{DAFTAR PUSTAKA}

1. Rasyidah M, Setyandriana Y. Pengukuran tekanan intraokular pada mata normal dibandingkan dengan mata penderita miop sebagai faktor risiko glaukoma. Mutiara Med. 2011;11(3):189-94.

2. Shields MB, Spaeth GL. The glaucomatous process and the evolving definition of glaucoma. J Glaucoma. 2012;21(3): 141-3.

3. Lane JT, Larson LA, Fan S, Stoner JA, Margalit $\mathrm{E}$, Toris $\mathrm{CB}$. Intraocular pressure and aqueous humor flow during a euglycemic- hyperinsulinemic clamp in patients with type 1 diabetes and microvascular complications. BMC Ophthalmol. 2010;10(1):1-8.

4. Suhardjo, Hartono S. Buku Ilmu Kesehatan Mata [Internet]. 2013. Available from: http://mitrahukum.org/wpcontent/uploa ds/2012/09/Jurnal-2.pdf

5. Anderson DR, Drance SM, Schulzer M. The effectiveness of intraocular pressure reduction in the treatment of normaltension glaucoma. Am J Ophthalmol. 1998;126(4):498-505.

6. Jo SH, Lee CK. The effect of caffeinated energy drink consumption on intraocular pressure in young adults. J Korean Ophthalmol Soc. 2015;56(7):1096.

7. Whalen DJ, Silk JS, Semel M, Forbes EE, Ryan $\mathrm{ND}$, Axelson DA, et al. Caffeine consumption, sleep, and affect in the natural environments of depressed youth and healthy controls. J Pediatr Psychol. 2008;33(4):358-67.

8. Ebeigbe J, Obahiagbon E. Acute effects of consumption of energy drink on intraocular pressure and blood pressure- 
52 Medical Scope Journal (MSJ), Volume 2, Nomor 2, Januari-Juni 2021, hlm. 48-52

pilot study. African J Med Heal Sci. 2013;12(1):20.

9. Azimah N, Aziz A, Nurfahmi A, Ali A, Kamarudin MN, Shaari NA, et al. Coffee intake and progression of glaucoma. 2015;3(1):7-11.

10. Putri BWS, Widodo WH, Sulistyoningrum EMS. Efek akut konsumsi kopi berkafein terhadap peningkatan tekanan intraokular pada mahasiswa Jurusan Kedokteran Univeristas Jendral Soedirman. J Chem Inf Model. 2013;53(9): 1689-99.

11. Chandra P, Gaur A, Varma S. Effect of caffeine on the intraocular pressure in patients with primary open angle glaucoma. Clin Ophthalmol. 2011;5(1): 1623-9.

12. Avisar R, Avisar E, Weinberger D. Effect of coffee consumption on intraocular pressure. Ann Pharmacother. 2002; 36(6): 992-5.

13. Jiwani AZ, Rhee DJ, Brauner SC, Gardiner MF, Chen TC, Shen LQ, et al. Effects of caffeinated coffee consumption on intraocular pressure, ocular perfusion pressure, and ocular pulse amplitude: A randomized controlled trial. Eye [Internet]. 2012;26(8):1122-30.

14. Fidelma N, Sydney EC. The effect of graded doses of caffeine on intraocular pressure in Niger Delta, Nigeria. J Adv Med Med Res. 2019;29(9):1-6.

15. Pasquale LR, Wiggs JL, Willett WC, Kang JH. The relationship between caffeine and coffee consumption and exfoliation glaucoma or glaucoma suspect: A prospective study in two cohorts. Investig Ophthalmol Vis Sci. 2012; 53(10):6427-33.

16. Rang JH, Willett WC, Rosner BA, Hankinson SE, Pasquale LR. Caffeine consumption and the risk of primary open-angle glaucoma: A prospective cohort study. Investig Ophthalmol Vis Sci. 2008; 49(5):1924-31.

17. Ajayi BO, Ukwade M. Caffeine and intraocular pressure in a Nigerian population. $\mathbf{J}$ Glaucoma. 2002;11(2):169.

18. Hastuti DS. Kandungan kafein pada kopi dan pengaruh terhadap tubuh. Media Litbangkes. 2015;25(3):185-92.

19. Okuro M, Fujiki N, Kotorii N, Ishimaru Y, Sokoloff P, Nishino S. Effects of paraxanthine and caffeine on sleep, locomotor activity, and body temperature in orexin/ataxin-3 transgenic narcoleptic mice. Sleep. 2010;33(7):930-42.

20. Wright P. Atlas of Ophthalmology. $\mathrm{Br} \mathrm{J}$ Ophthalmol. 1983;67(10):712. 